\title{
'I And My Family We Shall Serve The Lord': Reflections on the Identity of the Pastor's Wife in Ghanaian Charismatic Ministries
}

\begin{abstract}
Pastor's wives in Charismatic ministries in Ghana face similar challenges like what happened to the Zipporah, the wife of Moses. All these women feel less secure within the worship space and are easily demeaned. These pastor's wives find themselves caught between substance and liminal identities, acceptance and rejection. Such attitudes towards them is similar to the way Ghanaians treat ntwema ("red clay") used to maintain, beautify and protect the home. It is very useful yet kept in homes as if it is insignificant or unwanted. This paper uses an ideological reading of Exodus 4:18-26 and 18:1-27 to highlight the life and challenges of Zipporah and uses the findings to reflect on the experiences of the pastor's wife in Ghanaian charismatic tradition. It presents views of two focus-groups of pastors' wives in Accra and Kumasi, made up of ten (10) women each. All the twenty women are wives of founders of charismatic ministries and are ordained. It proposes that the pastors must always be grateful to their spouses. The Church should also not downplay the role of in-laws, mediators and wise counsellors who intervene when there are problems. More so, pastors' wives must draw from their inner strength to affirm their own personality, worth and dignity.
\end{abstract}

Keywords: Zipporah, Moses, pastor's wife, Charismatic ministries, liminality

\author{
MARK S. AIDOO ${ }^{1}$ \\ ${ }^{1}$ Mark S. Aidoo $(\mathrm{PhD})$ is a Lecturer \\ in Old Testament and Hebrew, and \\ Director for Research at Trinity \\ Theological Seminary, Legon, Ghana. \\ Email:macsaidoo@gmail.com
}

\section{Manuscript \\ Received 27th April 2020, \\ Accepted 26th June 2020, \\ Published online 16th July 2020.}

\section{INTRODUCTION}

This paper seeks to highlight some ways in which the pastor's wife in charismatic tradition is signified in Ghanaian society. It uses the story of Moses' wife, Zipporah, as well as the ntwema ("red clay") used in Ghanaian homes to symbolise the pastor's wife. It argues that the pastor's wife is caught between substance and liminal identities, acceptance and rejection. The purpose is twofold. The first is to explore the story of Zipporah to affirm ideological ways in which the pastor's wife is taken for granted. It employs an ideological reading of Exodus 4:18-26 and 18:1-27 to reveal the social tensions that characterize Zipporah's identity constructions as a type of a pastor's wife. Zipporah's story is not the only one to be remembered by Africans, but also one to be celebrated. She is a representative of the marginal African woman, and as the wife of a leader of a worshipping community, her story ought to be retold with dignity, not shame. A reading that will confer dignity must concentrate on exposing the structures, values, and concerns that hinder personal growth in contemporary pastoral ministry. The second is to explore the psychosocial experiences of the pastor's wife in Ghana. Views of two focus-groups of pastors' wives in Accra and Kumasi, two of the big cities in Ghana, are presented. Each of the focus-groups is made up of ten (10) women. The aim is for the wives to express what they see about themselves in the eyes of others and to reflect on those experiences.

This paper uses ideological exegesis. It is a method that allows interpretations of identity to open possibilities for ideological conceptualization and symbolism. Ideology, according to Roger Griffin, is "a relatively cohesive, dynamically evolving, set of collectively held ideas or beliefs, whether expressed verbally or in some other semiotic, 
performative, ritual, artistic or behavioural form."' That is to say, it is an interpretation of what people think and have come to know about a situation. Ideological readings examine the ways in which texts and their implied authors promulgate ideologies and in turn influences readers in their interaction with those ideologies to betray their own. David Clines also observes that ideological readings arise out of texts, speech, customs, images, political systems, customary behaviour in families, and social events. They serve as signifying practices that elicit understanding and critique in a close confrontation in order to evaluate the text according to our own values. ${ }^{3}$ On his part, Erich Zenger argues that a "serious ideological criticism should not begin with associations that first occur to the modern person when reading or listening to a particular text. The text, which has to be allowed to express itself on its own terms, functions as the starting point. An outspoken Hermeneutik des Verdachts (hermeneutic of suspicion) follows as the second stage." 4

\section{Zipporah as The Pastor's Wife}

The Old Testament had worship leaders like Priests and Levites. This paper assumes that the worship leader in the Old Testament is like the pastor in contemporary times, and the wife qualifies to be a pastor's wife. Generally, women of the Old Testament, no matter the position of their husbands, stood on the threshold of an identity crisis. They were caught between significance and insignificance. One such woman was Zipporah, wife of Moses. Others include Tamar who had to stand on the threshold of two worlds, whether to act as a daughter-in-law or a wife of Judah (Genesis 38:1-30), and Esther who was a Jew but got a new identity as Queen for the Persians (Esther 4:1-8:17). Notwithstanding, the Bible also presents stories about women who were co-builders of history, no matter how "flat" they were characterized. ${ }^{5}$

Zipporah is a character found in the book of Exodus. The book of Exodus is in two parts. First, it relates the drama of a people called to go out (the literal meaning of 'exodus') from slavery towards autonomy, and second it details worship practices and expectations at Sinai. ${ }^{6}$ Some women played key roles in the build-up to the worship and led during worship time. Carol Meyers observes that "Only six women (Elisheba [Exodus 6:23], Jochebed [Exodus 6:20], Miriam [Exodus 15:20, 21], Puah [Exodus 1:15], Shiphrah [Exodus 1:15], and Zipporah [Exodus 2:21, 4:25, 18:2]) are mentioned by name in the book of Exodus." " Out of the six, only Miriam is actively associated with the worshipping community of Israel: she is called a prophetess and she leads the women to sing praises to God for delivering them from the hands of the Egyptians (Ex. 15:20-21).

Zipporah, the wife of Moses, is the named woman given prominent attention in the book of Exodus. She is first mentioned as Reuel's gift to Moses in appreciation for helping his daughters (Ex 2:16-22). So, Zipporah, the Midianite, became the wife of Moses. When Moses was sent to embark on the mission to redeem the people of God, he travelled with Zipporah and his two sons. God had commissioned Moses as the leader of the people called out of Egypt to go and worship the Lord. As a worship leader, Moses enjoyed all the privileges like a priest. Priestly duties are indicated, for example, when Moses puts blood in a basin and dashes it against the altar as a sign to enact the covenant (Ex 24:6). He also makes atonement for sins (Ex 32:20), sets bread and lampstand before the Lord, and offers fragrant incense and burnt offerings at the entrance of the tabernacle (Ex 40:23-29). He also washes himself whenever he enters the tent of meeting just like Aaron, his brother, the high priest, and Aaron's sons (Ex 40:30-32). Given these actions, indicative of priestly tasks, one can say that in all likelihood Moses enjoyed the status and the privileges that attend priesthood. Moreover, the Danite priesthood draws its lineage from Moses, suggesting that the sons of Moses are priests (Judges 18:30), and the psalmist puts it succinctly: Moses and Aaron are priests (Ps 99:6). The priesthood of Moses is implied even in the New Testament (Hebrews 3:1-6). Early Jewish historians like Philo and Josephus also admit that Moses is a priest. For Philo, Moses served as a priest during the ratification of the covenant and Josephus says Moses was the high priest during the worship in the wilderness. ${ }^{8}$ With Moses in the role of priestly leader, it may not be out of place to see Zipporah as wife of a priest.

On the journey, Zipporah crossed a significant gender boundary and acted decisively and authoritatively, much like a lady-pastor when en route to Egypt. In the odd - and probably incomplete and corrupted - text of Exodus 4:1826, the delicate balance of life and death drive the plot of the story. It is odd because as Moses travelled from Midian to Egypt to deliver the people of Israel out of bondage, he faced a near death situation. The story mentions that God asked

\footnotetext{
2 Roger Griffin, “Ideology and Culture,” Journal of Political Ideologies, 11 (2006): 78.

David J. A. Clines, Interested Parties: The Ideology of Writers and Readers of the Hebrew Bible (Sheffield: Sheffield Phoenix Press, 2009), $14,15,20$

4 Erich Zenger, "Psalm 87: A Case for Ideological Criticism," in Reading from Right to Left: Essays in honour of David J.A. Clines, eds., J. Cheryl Exum and H.G.M. Williamson (London: T\&T Clark, 2003), 451.

5 Sharon H. Ringe, "When Women Interpret the Bible," in Womens Bible Commentary, Expanded Edition, eds., Carol Newsom and Sharon H. Ringe (Louisville: John Knox Press, 1998), 3.

6 Mark S. Aidoo, “The Book of Exodus as a Liturgical Drama," Kagoro Journal of Theology 1.1 (2016): 122-133.

Carol A. Meyers, Exodus, New Cambridge Bible Commentary (Cambridge: Cambridge University Press, 2005), 25

See John Lierman, The New Testament Moses: Christian Perceptions of Moses and Israel in the Setting of Jewish Religion, Wissenschaftliche Untersuchungen zum Neuen Testament 173 (Tübingen: Mohr Siebert, 2004), 67,68.
} 
Moses to go back to Egypt, for all the people who wanted to kill him were dead (Ex. 4:19). Moses, however, sought permission from his father-in-law to go to Egypt because he wanted to find out if any of his own people were still alive (Ex 4:18). As Moses travelled with Zipporah and their two sons, they lodged at an inn, and "the Lord sought to kill him" (4:24). The pronoun "him" here is ambiguous, for there were three males traveling with Zipporah to Egypt: Moses, Gershom, and Eliezer. One of them had become the target of the Lord, and no reason is given for the attempted killing. ${ }^{9}$ Moses ought to be grateful for a wife like Zipporah who stepped up to do what was unusual but also highly effective in saving the life of either her husband or sons. Concern for her family made Zipporah intervene "to cut off the foreskin (Hebrew: 'arlah) of her son" (4:25). The narrator avoids the term "circumcision," (Hebrew: $m u l$ ) perhaps to clarify that Zipporah's act does not amount to the ritual Jewish practice of circumcision, which signifies male participation in the covenant. ${ }^{10}$ In Genesis 17:11 circumcision goes with cutting of foreskin: "You shall circumcise (unemalttem) in the flesh of your foreskins ( 'arlatkem) and it shall be a sign of the covenant between me and you." According to Gwynn Kessler, with the act of circumcising Zipporah transgressed her gender boundaries and intruded into the male arena. ${ }^{11}$ If this is so, then Zipporah was caught between two worlds: to save the husband from dying, and to fulfil a command to circumcise. This woman in Moses' life endangered herself to stop a deadly attack - in this instance thwarting divine intent. Susan Ackerman asserts that through the circumcision and her formulaic pronouncement, Zipporah became a ritualistic specialist. ${ }^{12}$

Bernard Robinson expands the implication of Zipporah's action as a way of saving all Israel. He says, "The action was appropriate in view of the way in which Moses represents the whole people. Israel's life-blood would be spared because of the vicarious shedding and smearing of the blood of the Passover lamb, just as here Moses is spared because of the blood of Gershom." ${ }^{13}$ The cutting off the foreskin here also serves as removing the boundary between Jews and non-Jews, and bridging the rituals between Jewish men and women. ${ }^{14}$ By the act of circumcision, Zipporah did what Moses failed to do and it made the sons break from their past to associate with the Abrahamic covenant - the old is gone: "Any uncircumcised male, who has not been circumcised in the flesh, will be cut off from his people; he has broken my covenant" (Gen. 17:14). As such, Zipporah's act is that of a wise and brave woman whose initiative makes her the saviour of the family. She made a move so that the males would not be cut off from the people of God.

Zipporah's ability to discern God's intention to kill Moses may be a gift that she possessed. Discerning the will of God is no ordinary gift. In Christian interpretation, discernment is a spiritual gift from God (1 Cor. 12:10). She may therefore qualify as a spiritual leader; one who taps into the fundamental needs of both the worship leader and followers to bring about spiritual well-being. The spiritual leader is also one who is led by the Spirit to exercise a task with its value congruence, and promote that which fosters a relationship with God toward social well-being. Spiritual leaders could be followers and not necessarily "leaders". So even followers can draw from their inner spiritual strength to initiate a God-given agenda to transform lives of leaders and manage situations. ${ }^{15}$ Spiritual leaders in this sense work primarily on what God expects to be done. Zipporah thus joins the list of foremothers with spiritual gifts, and spiritual women whose spirituality empowers them to pursue the agenda of God in situations where the leader fails to do what is expected. Zipporah the follower ends up protecting the one who was to minister to the Lord's people. Just as Moses escaped death as a child because of the compassion of an African woman who was the daughter of Pharaoh, Zipporah's timely move though a foreigner among the Israelites saved Moses from death as an adult.

God sent Moses to go to Egypt and lead His people into the wilderness to worship Him and offer sacrifices (Ex $3: 12,18 ; 5: 1,3)$. If Pharaoh refused to allow Israel to go and worship the Lord in the wilderness, the Lord would strike the Egyptians with plagues that would influence them to give up $(3: 20 ; 4: 23)$. The Egyptians eventually gave up for Israel to go and worship God. After the people of Israel crossed the Red Sea into the wilderness, the songs of Moses and Miriam rightly ushered them into the space of worship (Ex 15:1-21). Significantly, Zipporah the Midianite woman was among the "people of God" in worship. Yet Moses did not want to serve the Lord with his family.

\footnotetext{
The argument about who is a target has elicited long debate. See Brevard Childs, The Book of Exodus: A Critical, Theological Commentary, OTL (Louisville: Westminster Press, 1974), 95-101; Fred Blumenthal, “The Circumcision performed by Zipporah,” Jewish Bible Quarterly 35 (2007): 256. Some suggest is that it is probable that Moses is the intended target. See Childs, The Book of Exodus: 98,101; Terrence Fretheim, Exodus, Interpretation (Louisville: Westminster John Knox, 2010).75-79; John H. Dobson, A Guide to Exodus, SPCK International Study Guide 13 (London: SPCK, 1977), 29; James K. Bruckner, Exodus, NIBC (Peabody: Hendrickson Publishers, 2008$)$, 54.

10 Some rabbinic interpreters, in an attempt to take the credit away from her, say Zipporah did not actually complete the circumcision. They argue instead that Zipporah started it and Moses completed it. See Gwynn Kessler, "Let's Cross that Body When We Get to It: Gender and Ethnicity in Rabbinic Literature," Journal of American Academy of Religion 73. 2 (2005): 343.

11 Kessler, "Lets Cross that Body when we get to it: Gender and Ethnicity in Rabbinic Literature," 331, 339.

12 Susan Ackerman, "Why Miriam is also among the Prophets? (And is Zipporah among the Priests?)," Journal of Biblical Literature 121.1 (2002): 74.

13 Bernard P. Robinson, “Zipporah to the Rescue: A Contextual Study of Exodus IV.24-6,” Vetus Testamentum 36.4 (1986): 458.

14 Kessler "Let's Cross that Body when we get to it: Gender and Ethnicity in Rabbinic Literature," 332.

15 Mark S. Aidoo, "Empowering Followership in the Politics of Workplace Spiritual Leadership," Expository Times 128.8 (2017): 369. See also Louis W. Fry, “Towards a Theory of Spiritual Leadership,” The Leadership Quarterly 14 (2003): 710-717.
} 
In Exodus 18:1-27, the storyteller hints that Moses sent Zipporah away. Moses sent his wife away (Heb: shilluchayha) together with his two sons back to Jethro her father for some unknown reason (18:2). ${ }^{16}$ When and how the sending away happened is obscure. As Childs puts it, the sending away "does not fit in too well with the ongoing narrative." ${ }^{17}$ The general translation is that Moses sent her away or sent her home, so it is possible that Moses did not want her to be with him. Alan Cole suggests that later Hebrew interpretation of the verb means to divorce. ${ }^{18}$ The Hebrew root, slh meaning "send away, throw away, dismiss," also implies a forceful rejection, a sending away or divorce. ${ }^{19}$ In Deuteronomy 24:1, the marriage law stipulates that one could write a bill of divorce and give it the wife who has lost favour in the husband's eye and "send her away". Taking Moses' action as divorce is not the focus of this paper. Some scholars trying to be sympathetic with Moses explain that he sent Zipporah and the children away so that Pharaoh could not harm them, although that is not stated in the Bible. ${ }^{20}$

Following the NRSV, NIV, NJB and ESV that Moses sent the wife and children home, it could be assumed that Moses" action was to cut off Zipporah, his "helpmate," "saviour" and "bridegroom of blood" from being part of the covenant-making at Sinai. He treated her as someone who can be sent home when he is on his way to go and worship the Lord. Even though his family was supposed to be part of the covenant people, Moses sent them away. Jethro, however, acted swiftly: "After Moses had sent away his wife Zipporah, his father-in-law took her back" (18:2). ${ }^{21}$ Jethro as a father, he did not reject his daughter and grandsons. Jethro sought for reconciliation. When they arrived at the camp of Israel, Jethro appreciated "all that God has done for Moses" (18:1). Jethro had heard "all," and it is probable that included all that Zipporah had done for Moses.

Jethro, like his daughter Zipporah, stepped in, and took an initiative. He sent word to Moses in the wilderness, "I, your father-in-law Jethro, am coming to you with your wife and her two sons with her" (18:6). The emphasis, "I, your father-in-law" points to legitimation and authority of his word. ${ }^{22} \mathrm{He}$ did not count only on his office as priest but used the most authoritative title - father-in-law. Among the Akan, the father-in-law wields much authority and can make or unmake a marriage contract. Similar authority may be indicated here. Such an introduction - father-in-law - placed Moses on edge. Jethro, a wise and courteous man, knew how to address injustice. He first informed Moses of their coming. According to Fred Blumenthal, "It is quite possible that he considered it a task to be carried out in order to eliminate injustice and then upon the completion of this task he would return to Midian. Perhaps he intended to act like a humanitarian who would lend his strength and conviction to wipe out the cruelties being done to his people without having to become a permanent member of their group." ${ }^{23}$ In other words, Jethro's intervention was aimed at addressing the injustice meted out to his daughter and grandsons. Moses, the worship leader, had been ungrateful to his family.

The warm reception Moses gave Jethro when they met can be described as an emotional ploy. The implied author specifically ignored the presence of Zipporah and the children. Moses went out to meet his father-in-law and showed him affection: "he bowed down and kissed him" (18:7). ${ }^{24}$ The silence of the implied author concerning how Moses received his wife and children is too loud. The exchange of pleasantries excluded the wife and sons. The allmales affair made Zipporah socially liminal and unimportant. As they sat to talk, Moses told Jethro only what God has done for Israel and the hardships they faced along the way (18:8). After hearing everything, Jethro gave praise to God and offered a burnt offering and sacrifice to the Lord. Now Jethro is ready to act as a priest, so he joined Aaron and all the elders of Israel "to eat bread" in the presence of the Lord (18:12). In many African cultures, including the Akan, reconciliation is sealed with eating together that is food served from the same pot. The couple must partake of the meal but in the text, it seems Zipporah was excluded. The significance of eating together is also an ideological and psychological symbol to promote intimacy. It also serves as a sign of peace.

\section{The Pastor's Wife in perspective}

In Ghana, the Charismatic churches were a direct outcome of the evangelical/charismatic renewal in the 1960's and 1970's which swept across the country. ${ }^{25}$ The terms "neo-Pentecostal" and "charismatic" are usually used interchangeably but can depict different brands of modern Christianity. They are generally the newer and younger Pentecostal independent

16 In Exodus 18, Zipporah's father is called Jethro. He is the same as Reuel in Exodus 4.

17 Childs, Exodus - A Critical, Theological Commentary, 326.

18 Alan Cole, Exodus, Tyndale Old Testament Commentaries (London: InterVasity Press, 1973), 137-138

19 John I. Durham, Exodus, WBC (Waco: Word Books, 1987), 238.

20 Dobson, Exodus, 98; Bruckner, Exodus, 164.

21 Most English versions use "took" while the NIV uses "received."

22 Brevard Childs (Exodus - A Critical, Theological Commentary 327), however, thinks the emphasis on "father-in-law" produces an atmosphere of polite formality.

23 Blumenthal, "The Circumcision performed by Zipporah," 257.

24 Kissing and embracing are cultural ways of welcoming friends and relatives. For example, see Genesis 27:11; 29:11; 48:10; 50:1; Exodus 4:27; 2 Samuel 19:39. Emphasis mine.

25 Cephas Omenyo, Pentecost Outside Pentecostalism: A Study of the Development of Charismatic Movements in Mainline Churches (Leiden: Uitgeverij Boekencentrum, 2006), 96. See also Asamoah-Gyadu, African Charismatics, 26. 
and parachurch movements, many of which function within non-Pentecostal denominations. ${ }^{26}$ For Paul Gifford, "Pentecostalism is a homogenous religion; it is as heterogeneous in character as it is in mission. For instance, in Ghana, Classical Pentecostalism has gradually lost its monopoly to the neo-Pentecostal churches or Charismatic Ministries/ Churches (CMs/CCs) that began in the late 1970s." ${ }^{27}$ The neo-Pentecostal and charismatic churches, like Pentecostal churches, emphasize on the gifts of the Holy Spirit and more of indigenous independent movements. They pursue a western-style of worship and engagement with a radical pursuit of abundant life and wage a strong war against evil spirits. Worship in these churches is exuberant and every member is allowed to exercise the gifts of the Holy Spirit in building up the faith.

Unlike pastoral ministry in the Pentecostal tradition, the pastors in charismatic Churches ordain their wives. ${ }^{28}$ Jane Soothill mentions three main features of gender discourses that distinguish charismatic Christianity from the older mission-style churches. She says the charismatics remove "traditional barriers to female leadership and the exercise of official authority by women in the churches' organisational structures." They highlight "social change and social renewal, important elements of which are directed towards male behaviour that may be damaging to women", and they emphasize the "personal development of individuals, especially women, and the importance of encouraging women to build on their self-confidence and self-esteem." ${ }^{29}$ That is to say the wives of pastors play key roles in the husband's ministry.

The two focus-group meetings on which the following section is based were held in July and November 2018. All the twenty women in Accra and in Kumasi are wives of founders of charismatic Churches and are ordained. They revealed that ordination depends on the woman if she is interested. They admitted that the wife of a pastor in Charismatic Churches is expected to play a significant role in the pastoral ministry of her husband but with so many limitations. To them, when the man or woman feels called by God to be a pastor, the spouse must accept to be a co-pastor to support the work. Rachael Lovingood and Jennifer Landrith identify four types of calling associated with pastors' wives: specific calling; general calling; unexpected calling and impersonal calling. ${ }^{30}$ A pastor's wife has at least one of such callings and they may be called co-pastors or lady pastors. Brigid Sackey also posits that spouses play key roles in the ministry. She says: "Some people may come to you simply because you are a pastor's wife and tell you their problems. Sometimes women can relate better to women and therefore it is essential for pastors wives to be ordained to minister together." 31 They admitted that the wife or lady-pastor is the focal point for rallying women in the congregation and seeing to the concerns of women. So, she must not be so prominent in the domain of male congregants. She must be a good speaker and teacher. She must be prayerful and provide counsel to whoever stands in need.

An ordained pastor's wife cannot act as the pastor in charge if the husband is away. She may wield a considerable amount of authority in the husband's decision-making but not that office. All the wives admitted that they do not take it lightly when their husbands do not listen to them when making decisions in the Church. That is to say, the co-pastor or lady-pastor plays a key role in Church administration but not even as the acting head of the ministry. However, five women in Accra and eight in Kumasi said that their husbands prefer they do not speak at executive meetings. They should find appropriate ways to communicate their thoughts through their husbands.

Generally, the wife of the pastor is also considered as the 'first-lady' of the Church, ${ }^{32}$ a nomenclature borrowed from political leadership. They thus assume a lot of political authority in the Church, especially over women congregants. The focus-group participants revealed that they see themselves as the managers of their husbands ministry. Two of them said they act like the personal secretaries to their husbands. No colleague minister, whether a bishop, a pastor

26 Scholars observe three strands of the Pentecostal ministries in Ghana. The first is the African Independent Churches (AICs) also called Spiritual Churches. The second is the western-related missions but with indigenous initiatives referred to as the Classical Pentecostal denominations which include the Church of Pentecost, The Apostolic Church of Ghana, Christ Apostolic Church, Ghana, Elim Pentecostal Church, and Assemblies of God. The third is the renewal movements in Catholic churches, mainline protestant churches, as well as the neo-Pentecostal, and charismatic ministries. See J. Kwabena Asamoah-Gyadu. African Charismatics: Current Developments within Indigenous Pentecostalism in Ghana (Leiden: E.J. Brill, 2005), 2; E. Kingsley Larbi, Pentecostalism: The Eddies of Ghanaian Christianity (Accra: Centre for Pentecostal and Charismatic Studies, 2001), 77.

27 Paul Gifford, Ghana's New Christianity: Pentecostalism in a Globalizing African Economy (London: Hurst and Co., 2004), viii, ix.

28 Ernestina Enyonam Novieto, "Women Leaders In Ghanaian Pentecostal/ Charismatic Churches" (PhD Thesis Study of Religions, Universiy of Ghana, Legon, 2013), 4, 88. Admittedly, not all neo-Pentecostal or Charismatic churches ordain the pastor's wife. Allan H. Anderson (An Introduction to Pentecostalism, $2^{\text {nd }}$ ed [Cambridge: Cambridge University Press, 2014], 265-270), however, explores how Pentecostal congregations embrace women empowerment yet deny them of hierarchical positions of leadership.

29 Jane E. Soothill, “The Problem with 'Women's Empowerment': Female Religiosity in Ghana's Charismatic Churches,” Studies in World Christianity 16.1 (2010): 82-83.

30 Rachael Lovingood and Jennifer Landrith, In our Shoes: Real Life Issues for Ministers' Wives by Ministers' Wives (Nashville: LifeWay Press, 2008), 12-14.

31 Brigid M. Sackey, New Direction in Gender and Religion: The Changing Status of Women (Lanham: Lexington Books, 2006$), 173$.

32 Kudzai Biri, "Neo-Pentecostal Churches in Africa ('Prosperity churches')" in Anthology of African Christianity, eds. I.A. Phiri, D. Werner, C. Kaunda and K. Owino (Oxford: Regnum Books, 2016), 418. 
or a prophet can come to the pastor without passing through them. In reality, however, the wives hardly hear what the colleagues or visitors discuss with their husbands.

All the pastor's wives in question said that ideally, they enjoy equal access and opportunities in society by virtue of their husbands. In Ghana, women have overcome many barriers of discrimination and are recognized as leaders in the society. The respect and courtesies given to the pastor are also extended to them. The Charismatic Churches teach their members to respect both the pastor and the wife; disrespecting the pastor's wife is like disrespecting God. And yet, wives of the pastors are expected to remain subordinate to their husbands. ${ }^{33}$

In some cases, the pastoral ministry in Charismatic Churches serves as the site for constructing and projecting an identity of presence. On most of the Church's billboards, both the pastor and the wife are projected to define the image of the Church: an image that also visually represents the ideal of Christian marriage - between a man and a woman. The women do not take it lightly when they are not put on the billboards with their husbands. They argue that without their image, the man is vulnerable to seductive women. To them, it is not good for people to know the pastor alone. Five of the women admitted that they are the ones who add beauty to the billboards and make the advertisement attractive. They also represent the women and mirror the image of her husband before the congregation.

There are cases where the pastor's wife does not receive any salary or allowance from the Church no matter the work she performs. Nevertheless, she is expected to appear attractive and fashionable always. She must dress to surpass all the women in the congregation. Although they are pastors, they do not always dress in ministerial outfit. Their husbands prefer that they dress in traditional garments. They admitted that some of them overdress at times because of the competition among women in the Church. Arguing from another context, Michelle Lesley says that not all wives of pastors are arrogant, self-centered, elitist, untouchable, over-dressed, and powerful. ${ }^{34}$ For some of the Charismatic ministries, the more beautiful she is, the higher the image of the Church, which reinforces familiar gender stereotypes. If the pastors want to serve the Lord with their spouses, they must rethink about how to motivate them financially so that they gain from the work they do.

It is said that, "Pastors' wives are highly influential, esteemed, and recognized figures in their respective communities. As such, the public modeling of the pastor's wife as the 'first lady of the Church' is expected to help cultivate healthy relationships with women congregants and connect for gender bonding as well as spiritual guidance." ${ }^{35}$ Truly, they see themselves as models but cannot win more recognition than the pastor. Ironically, the pastor's wife must fight for her position as the number one lady of the Church and at the same time the number one woman in the life of the pastor. She must stand taller in status than all the other women. They feel recognized whenever the pastor introduces them first before preaching or ministration.

The identity of the pastor in Charismatic Churches is also seen in the type of throne or seat he sits on. The pastor's throne must be different from all others and none can use it whatsoever. Twelve of the wives said they sit on a similar chair as that of the pastor, while the others said they are given a special seat where most of the pastors sit. They all said they are given those seats because of the work of ministry. No matter where they sit in the Church, the pastor's wife must show unqualified subordination to the husband. She must succumb to the dominant gendered discourse, and must not affirm any other man's eminence. Jane Soothill makes a brilliant observation when she said, "African neoPentecostalism undermines gender as a definer of social status, but hierarchy, personality politics and the importance of leaders is left largely unchallenged by the presence of women in position of religious or political authority." 36

The groups complained that their husbands hardly stay at home. Some pastors take several days to fast and wait upon the Lord. They travel from one sacred mountain to another for days to fast and pray. Afterwards the pastor needs some space to prepare for a scheduled programme till it has been completed. Most of the time, the pastors are invited to minister in other Churches for days. If the wife is a career woman, she cannot go with the pastor. Even when the pastor is ministering in his own Church, a lot of time is spent away from home counselling and attending to the needs of others. Loneliness thus makes the women think they are not important. They also endure a lot of sacrifice as if they are single parents if the family is blessed with children. She must look on as the pastor engages more with others than with her.

Divorce seems to be rampant in the circles of pastors especially in Charismatic ministries. The pastors usually provide justifiable reasons why they must divorce their wives no matter the sacrifices the wives make. They usually complain that their wives are abusive in the marriage. Some use the example of Archbishop Nicholas Duncan Williams

\footnotetext{
33 Novieto, "Women Leaders in Ghanaian Pentecostal/Charismatic Churches," 236-239; Paul Sullins, "The Stained Glass Ceiling: Career Attainment for Women Clergy," Sociology of Religion 61 (2000): 234-266; Patricia M. Y. Chang, "Female Clergy in the Contemporary Pentecostal Church: A Current Assessment," Journal for the Scientific Study of Religion 36 (1999): 565-573.

34 Michelle Lesley, "Guest Post: A Lady First, Being a Pastor's Wife," in https://michellelesleybooks.com/2016/02/22/guest-post-a-lady-firstbeing-a-pastors-wife. Accessed June 12, 2018.

35 Kimberley S. Clay, Kelley Newtin, and Kimberley D. Leeks, "Pastor's Wives as Partners: An Appropriate Model for Church-based Health Promotion," Cancer Control (Nov 2006): 111-112.

36 Jane E. Soothill, Gender and Pentecostalism in Africa (Leiden: Brill, 2014), 212.
} 
who is held as the pioneer and father of Charismatic ministries in Ghana. Duncan Williams openly announced before a congregation his divorce notice to his wife during a Church worship service. ${ }^{37}$ With that floodgates opened, many more are suffering from all forms of discrimination and abuse. Since some of the Charismatic Churches do not operate under a larger sanctioning body, some of the pastors are try to do what they desire as long as they can justify it. In most cases, the social position of the pastor makes it difficult for the extended family of the woman or other pastors to intervene when the marriage is in crisis. The experiences of the pastor's wives are not unique. Other women go through similar situations of identity crisis as they avail themselves to participate in worship. Such stories identify the woman as a person of worth yet remains liminal.

\section{Symbolizing the Pastor's wife in Akan Perspective}

A symbol that comes close to the liminality the pastor's wives experience is how the ntwema is treated in the lives and thoughts of the Akan people . In the traditional Akan home setting, the hearth mirrors the center of life. Without cooking, the African home is lifeless. The hearth is a three-legged stand made of clay or mud for cooking. Each stand is cylindrical in nature with the bottom part larger than the top. The clay must be devoid of stones and sand to avoid cracking when fire is set. Naturally, firewood used in the hearth produces a lot of smoke so the walls around an enclosed kitchen will definitely be coloured with black smoke. To restore the walls to its colour and to maintain the hearth from cracking, the ntwema is used. Periodically, the hearth and walls around the hearth must be painted with the ntwema. A hard-working woman maintains the hearth every morning. Hence, the identity of a good wife is in how she uses ntwema. There are instances where the ntwema is used on cooking pots that are put on the hearth so that the smoke does not stick on the pots. A woman whose pots are stained with black soot is considered a lazy woman. When a home does not have ntwema, the woman of the house attracts a bad image for herself. Life in the home is dimmed when the hearth is in bad shape.

In the past when mud houses were the norm, the red clay mixed in water served as a plastering agent for the internal walls to seal cracks and hiding places of small insects. Moreover, interior surfaces painted with the ntwema beautified the walls and kept the walls from cracks. The aesthetic function added prestige to the owner of the house. A room painted with ntwema remained cool even in high temperatures. Every good home could not do without the ntwema. In another vein, the ntwema was used as an identifying mark on close family members who are mourning. Among the Ashanti, these marks are called asaafa. About three lines are drawn with the red clay on the arms of the family members to identify them as those who are mourning. It is believed that the marks can ward off the influence of ghosts on the mourners.

In spite of its value, the ntwema is taken for granted. It is usually kept at the corner near the washroom or at the back of a house. It has no place in the kitchen. The mixture is usually made in old containers that cannot be used in the kitchen any longer. In all, the red clay in Akan though is a very significant symbol of protection, beauty, health and honour, is not properly kept. Like the ntwema, the pastor's wife is significant yet taken for granted. Even where they are supposed to be visible, their identity goes unnoticed or discarded which creates more challenges.

\section{Redefining Pastoral Ministry}

Stories about pastors' wives come with their own dynamics. In most cases, asking the woman to silently suffer is out of the question. The push-and-pull between intimacy and rejection for the pastor's wife is a real thing. The sense of commitment to the Lord may play a key role in her ministry but the struggles for identity makes it extremely difficult. And there is very little room for pastoral care for pastors as well as the pastor's wife. Longwe laments how there are no traditional marriage counsellors for pastors' wives in Malawi. ${ }^{38}$ Admittedly, some Charismatic ministries have counsellors for pastors and the hope is that all should have such opportunities. Akan families know that marriages are communal and as such there must be godparents behind every marriage. Thus, during the celebration of the traditional marriage, both families nominate a person to serve as the godfather and/or godmother behind the new couple. They are advised that they should share all their relationship challenges with their godfathers and godmothers. Akan society does not permit a couple to live together without such communal support.

Some Christian traditions and theologies, however, downplay the concept of godfathers and godmothers and so couples suffer with no support. Others advocate that couples never share their problems with anyone except God. Some couples are having challenges in their relationship and have resorted to prayer endlessly without any hope. They forget that God works through people. Downplaying the role of Jethros in marriage is definitely costing the Church. Where

37 Jane Soothill, "Gender and Pentecostalism in Africa," in Pentecostalism in Africa: Presence and Impact of Pneumatic Christianity in Postcolonial Societies, ed. Martin Lindhardt (Leiden: Brill, 2015), 206; Emmanuel K. Dogbovi, "The Duncan-Williams marital conundrum: Who bells the cat?" Myjoyonline 21 April 2008 in https://www.myjoyonline.com/opinion/the-duncan-williams-marital-conundrum-whobells-the-cat/\#! Date accessed 15 May 2020.

38 Molly Longwe, "Pastor's Home as a Safe Space? A Critical Feminist Analysis of the Experiences of Pastors' Wives in the Baptist Convention of Malawi (BACOMA)," Journal of Theology for Southern Africa 146 (July 2013): 50,51. 
there are no professional marriage counsellors, the Churches must find alternatives when problems arise. Christians must appreciate that when the pastor's wife suffers, there must be others empowered to be there for them (cf Lam. 1:12a; Gal 6:1-3). There must be persons with a pastoral heart who can address the challenges of worship leaders and act swiftly to bring about reconciliation.

Texts that give little opportunities to women must invite readers to speak out for justice. Even Moses must not be spared. Negative portrayal of women and situations that take them for granted are detrimental to the holistic growth of the Christian ministry and humanity in the image of God. The worship space is supposed to support both man and woman in all the stages of life. It should not be a place where the Zipporahs are sent home while the Moses' move out to go and worship. It should be a place where there are many Jethros. How can a neglected spouse be welcome in the house of God which he/she helped to build? Without resolving the developmental stage of intimacy, there is the likelihood that stagnation will set in, creating negative images. There will be little room to conceive gleeful spiritual wellbeing or positive resolution. The pastor's wife should not be ordained only to sit on the sidelines.

In some marriages, men take women for granted and women take men for granted. For example, one partner does not appreciate what the other does, does not seek the opinion of the other, or marginalizes the other because he or she is of some higher status. Vine Deloria also mentions sexual differentiation as an area in which both men and women take each other for granted. ${ }^{39}$ Writing from the Bini tribe in Nigeria about 2 decades ago, Mercy Itohan Idumwonyi asserts that "the woman's unique position in the society has always been disregarded and denied. She is treated as a mere catalyst in the realms of development and a complementary tool." ${ }^{\text {40 }}$ Such a description cannot be said to have been completely changed. The effects may get worse when both the man and woman are pastors or share pastoral responsibility over the same congregants. Sometimes, women who are the main pastors (that is a pastor in charge and not an assistant pastor, co-pastor or lay pastor), are expected to play fluid roles as if they are "helpmates" of the husbands in ministry. Pastors and pastors' wives, however, must know the difference between Christian leadership after the model of Christ and other types of secular leadership. They must understand the difference between pastoral leadership and family leadership. Like Jesus, the pastors' wives need not entrust themselves to the expectations of the people (Jn 2:24-25).

Paul's words to the overseer included the man's relationship to his wife and his ability to manage the home (1 Tim 3:1-4). Pastors' wives of Charismatic ministries need their homes to be managed well. In today's world, some women sacrifice a lot for their households, cross gender boundaries and go the extra mile, support the home financially, and act courageously to avert the physical and spiritual threats on the pastors. However, they are denied the recognition due them. Such attitudes are "un-African". Oduyoye laments that, African community ethics abhor ingratitude, selfishness, and hypocrisy but some women continue to suffer from these ${ }^{41}$ When every couple tries to recollect what they have accomplished just as man counts his/her blessing to see what the Lord has done, there would definitely be opportunities to be grateful to each other. Longwe recommends that there should be mutual respect and recognition, mutual partnership and sharing of power, and service and humility in order to build a safe home. ${ }^{42} \mathrm{~A}$ home with such an ambiance can be assured for both the man and the wife. Each one needs the spouse's wisdom to succeed for the Akan say, nea orotwa sa no nnyim de n'ekyir akyea (lit, "the one creating a path does not know that the back is not straight"). The pastor cannot do it alone that is why the pastor and the family must serve the Lord together.

The Christian Church must continue to teach people to build homes without marginalization. Some Christians misinterpret the command to subdue and dominate in Genesis 1:28 as a task for the men alone and treat the wife as servants. Although the views solicited from the study group did not focus on domestic violence, it can be said in some sense that marginalization and discrimination against a wife can be considered as a kind of violence. Men have all the liberties but women are denied certain liberties at home. Longwe addressing a similar issue in Malawi observed that, "what is even more disheartening is that while the pastor's home is a haven for many people, the pastors' wives' and immediate families themselves have become victims of domestic violence." ${ }^{43}$ There is no doubt that some African women play significant roles but their stories are skewed to promote the oppressor. The African Church must preach the gospel of power that liberates and empowers women as created in the image of God, and affirm women's involvement in the community's social, religious and cultural affairs.

Lastly, the pastors' wives must explore inner ways of affirming their own personality and dignity. They must not look out for others to affirm their worth. They must not demean their own heroic contributions. They should know and accept the privilege of serving as a pastors' wives as a unique moment of grace and always be grateful for such

\footnotetext{
39 Vine Deloria, “The Sweetgrass Hills," in Sourcebook of World's Religions: An Interfaith Guide to Religion and Spirituality, ed., Joel D Beversluis (Novato, CA: New World Library, 2000), 338.

40 Mercy Itohan Idumwonyi, "Religious and Cultural Sustenance of Patriarchy in Africa: The Bini Woman's Dilemma," in Women and the culture of Violence in Traditional Africa, eds., Dorcas Akintunde and Helen Labeodan (Ibadan: Sefer, 2002), 100.

${ }_{41}$ Mercy Amba Oduyoye, Beads and Strands - Reflections of an African Woman on Christianity in Africa (Maryknoll: Orbis Books), 49, 54

42 Longwe, "Pastor's Home as a Safe Space?" 59.

43 Ibid., 44.
} 
a calling. Zipporah represents those whose wisdom and attentiveness promoted the wellbeing of a pastor's ministry. When it matters most, she suffers neglect, divorce and discrimination. ${ }^{44}$ However, memories about how such women have impacted lives in the worship space cannot be erased. Society needs to remember their achievements. The stories that capture the imagination of women who are victims of injustice and marital abuse can serve as lessons that speak to and for the voiceless women in their deepest aspirations and dignity thus becoming vehicles for the gospel of Christ. Their calling can be truncated but their experiences must live on.

\section{CONCLUSION}

To the African Christian, Zipporah is not the only heroine who suffered unjustly and liminaly. There are many others in the Charismatic ministries whose efforts are not recognized. The wives of pastors in Charismatic ministries echo the stories of modern day Zipporahs. The paper has also drawn on affinities between the symbolic significance of the ntwema in Akan worldview and pastor's wives who collaborate with their husbands in ministry. In these stories, the metaphor used and women play key roles in the lives of others but are liminal and remain at the margins. The women are made to feel less secure in the worship space since the men can easily reject them. The need for mediators who intervene when there are problems between the pastor and the wife is apt. Such mediators should be the wise counsellors, in-laws, godfathers and godmothers behind marriages whose roles bring about reconciliation.

The paper has challenged Christians to re-read stories about women whose husbands are worship leaders with an appreciative lens and calls on all followers of Christ to identify with those who contribute much to the success of leaders but are hardly acknowledged for it. Zipporah and other women in the Bible are not exceptions. Zipporah represents many women who suffer betrayal, denial, and divorce after all their sacrifices. Zipporah's story exemplifies the hostile sentiment against women and exclusion of certain women within the society. When Christians forget services that have been rendered in the past, it can end in the way Moses' marriage ended. Such texts teach all believers inclusivity.

\section{BIBLIOGRAPHY}

Ackerman, Susan. "Why Miriam is also among the Prophets? (And is Zipporah among the Priests?)," Journal of Biblical Literature 121.1 (2002): 47-80.

Aidoo, Mark S. "Empowering Followership in the Politics of Workplace Spiritual Leadership," Expository Times 128.8 (2017): 365-375.

Aidoo, Mark S. "The Book of Exodus as a Liturgical Drama," Kagoro Journal of Theology 1.1 (2016): 122-133.

Asamoah-Gyadu, J. Kwabena. African Charismatics: Current Developments within Indigenous Pentecostalism in Ghana. Leiden: E.J. Brill, 2005.

Blumenthal, Fred. "The Circumcision performed by Zipporah," Jewish Bible Quarterly 35 (2007): 255-259.

Chang, Patricia M.Y. "Female Clergy in the Contemporary Pentecostal Church: A Current Assessment," Journal for the Scientific Study of Religion 36 (1999): 565-573.

Childs, Brevard. Exodus - A Critical, Theological Commentary. Philadelphia: Westminster Press, 1974.

Clay, Kimberley S., Kelley Newtin, and Kimberley D. Leeks, "Pastor's Wives as Partners: An Appropriate Model for Church-based Health Promotion," Cancer Control (Nov 2006): 111-115.

Clines, David J. A. Interested Parties: The Ideology of Writers and Readers of the Hebrew Bible. Sheffield: Sheffield Phoenix Press, 2009.

Deloria,Vine. "The Sweetgrass Hills." In Sourcebook of World's Religions: An Interfaith Guide to Religion and Spirituality. Edited by Joel D Beversluis. Pages 335-340. Novato, CA: New World Library, 2000.

Fry, Louis W. "Towards a Theory of Spiritual Leadership." The Leadership Quarterly 14 (2003): 693-727.

Frymer-Kensky, Tikva. Reading the Women of the Bible- A New Interpretation of the Stories. New York: Schocken Books, 2002.

Gifford, Paul. Ghana's New Christianity: Pentecostalism in a Globalizing African Economy. London: Hurst and Co., 2004.

Griffin, Roger "Ideology and Culture," Journal of Political Ideologies, 11 (2006): 77-99.

Idumwonyi, Mercy Itohan. "Religious and Cultural Sustenance of Patriarchy in Africa: The Bini Woman's Dilemma." In Women and the culture of Violence in Traditional Africa. Edited by Dorcas Akintunde and Helen Labeodan. Pages 92-107. Ibadan: Sefer, 2002.

Kessler, Gwynn. "Let's Cross that Body When We Get to It: Gender and Ethnicity in Rabbinic Literature," Journal of American Academy of Religion 73. 2 (2005): 329-359.

Larbi, E. Kingsley. Pentecostalism: The Eddies of Ghanaian Christianity. Accra: Centre for Pentecostal and

44 Tikva Frymer-Kensky, Reading the Women of the Bible- A New Interpretation of the Stories (New York: Schocken Books, 2002), 32 
Charismatic Studies, 2001.

Lesley, Michelle. "Guest Post: A Lady First, Being a Pastor's Wife," in https://michellelesleybooks.com/2016/02/22/ guest-post-a-lady-first-being-a-pastors-wife. Accessed June 12, 2018.

Lierman, John. The New Testament Moses: Christian Perceptions of Moses and Israel in the Setting of Jewish Religion, Wissenschaftliche Untersuchungen zum Neuen Testament 173. Tübingen: Mohr Siebert, 2004.

Longwe, Molly. "Pastor's Home as a Safe Space? A Critical Feminist Analysis of the Experiences of Pastors'

Wives in the Baptist Convention of Malawi (BACOMA)," Journal of Theology for Southern Africa 146 (July 2013): 42-59.

Lovingood Rachael and Jennifer Landrith, In our Shoes: Real Life Issues for Ministers 'Wives by Ministers' Wives. Nashville: LifeWay Press, 2008.

Meyers, Carol A. Exodus, New Cambridge Bible Commentary. Cambridge: Cambridge University Press, 2005.

Novieto, Ernestina Enyonam. "Women Leaders in Ghanaian Pentecostal/Charismatic Churches." PhD Thesis, Department for the Study of Religions, University of Ghana, 2013.

Oduyoye, Mercy Amba. Beads and Strands - Reflections of an African Woman on Christianity in Africa. Maryknoll: Orbis Books.

Omenyo, Cephas. Pentecost Outside Pentecostalism: A Study of the Development of Charismatic Movements in Mainline Churches. Leiden: Uitgeverij Boekencentrum, 2006.

Ringe, Sharon H. "When Women Interpret the Bible," in Women's Bible Commentary, Expanded Edition. Edited by Carol Newsom and Sharon H. Ringe. Pages 1-9. Louisville: John Knox Press, 1998.

Robinson, Bernard P. “Zipporah to the Rescue: A Contextual Study of Exodus IV.24-6." Vetus Testamentum 36.4 (1986): 447-461.

Sackey, Brigid M. New Direction in Gender and Religion: The Changing Status of Women. Lanham: Lexington Books, 2006.

Sullins, Paul. "The Stained Glass Ceiling: Career Attainment for Women Clergy," Sociology of Religion 61 (2000): 234-266.

Soothill, Jane E. Gender and Pentecostalism in Africa. Leiden: Brill, 2014.

Soothill, Jane E. "The Problem with 'Women's Empowerment': Female Religiosity in Ghana's Charismatic Churches." Studies in World Christianity 16.1 (2010): 82-99.

Zenger, Erich. "Psalm 87: A Case for Ideological Criticism." In Reading from Right to Left: Essays in honour of David J.A. Clines. Edited by J. Cheryl Exum and HGM Williamson. Pages 450-460. London: T\&T Clark, 2003. 